\title{
Pengaruh Pertumbuhan Perusahaan, Kepemilikan Manajerial dan Kebijakan Dividen Pada Kinerja Perusahaan Manufaktur di BEI
}

\author{
I Wayan Diva Pradita Kamajaya ${ }^{1}$ \\ I.G.A.M. Asri Dwija Putri ${ }^{2}$ \\ ${ }^{1,2}$ Fakultas Ekonomi dan Bisnis Universitas Udayana (Unud), Bali Indonesia \\ e-mail: praditakamajaya@gmail.com
}

\begin{abstract}
ABSTRAK
Penelitian bertujuan untuk menganalisis pengaruh pertumbuhan perusahaan, kepemilikan manajerial dan kebijakan dividen pada kinerja perusahaan. Populasi yang didapat dalam peneliian ini adalah perusahaan yang terdaftar di Bursa Efek Indonesia. teknik purposive sampling dipilih untuk mengambil sampel yang memenuhi kriteria kemudian didapatkan sampel sebanyak 40. Pengukuran kinerja perusahaan dengan memakai rasio Tobin's Q. Pengujian hipotesisnya menggunakan analisis yang biasa digunakan yaitu analisis regresi linier berganda. Hasil penelitian hanya kepemilikan manajerial yang berpengaruh positif pada kinerja perusahan. Pertumbuhan perusahaan dan kebijakan dividen nyatanya tidak berpengaruh pada kinerja perusahaan.

Kata kunci: Pertumbuhan perusahaan, kepemilikan manajerial, kebijakan dividen
\end{abstract}

\begin{abstract}
This research was conducted to analyze the influence of company growth, managerial ownership and dividend policy on company performance. The population in this study are companies listed on the Indonesian stock exchange Samples were taken using purposive sampling technique and obtained 8 samples that met the criteria with the number of observations as many as 40. Company performance was measured using the Tobin's $Q$ ratio. Hypothesis testing was carried out using multiple linear regression analysis. The resultsshowed that the company's growth and dividend policy were concluded that it had no effect on the company's performance. While managerial ownership policies have a positive effect on company performance.

Keywords: Company growth, managerial ownership, dividend policy
\end{abstract}

\section{PENDAHULUAN}

Kinerja perusahaan menggambarkan kondisi keuangan suatu perusahaan dimana pengukuran dilakukan dengan menggunakan analisis berbagai rasio keuangan yang berguna untuk mengetahui bagaimana keadaan serta kemampuan keuangan perusahaan yang merupakan cerminan bagaimana prestasi kerja perusahaan dalam periode tertentu. Kinerja perusahaan juga digunakan untuk mengetahui tingkat keefektifan dan seberapa efisien manajemen dalam mencapai tujuan perusahaan. Menurut Syahnaz (2012), faktor penting untuk menilai keseluruhan kinerja 
perusahaan itu sendiri disebut kinerja perusahaan. Mulai dari penilaian asset, utang likuiditas dan lain sebagainya. Banyak indikator yang dipakai dalam menganalisa kinerja keuangan perusahaan, dalam penelitian ini alat yang digunakan untuk mengukur kinerja keuangan perusahaan adalah rasio Tobin's Q. yang menekankan pada pengelolaan aset oleh manajemen (Sudiyanto dan Puspitasari, 2010). Hal tersebut akan berdampak pada peningkatan nilai perusahaan yang berarti kemakmuran pemegang saham juga akan meningkat, yang secara tidak langsung juga berpengaruh terhadap pertumbuhan aset yang dimiliki perusahaan.

Pertumbuhan perusahaan sebagai perubahan aset tahunan dari total aktiva. Hal ini dapat dibuktikan melalui perusahaan yang tumbuh dapat dilihat dari peningkatan aktiva untuk memperbesar ukuran perusahaan (Brigham dan Houston, 2001). Penelitian yang dilakukan Jogiyanto, dkk (2002), menemukan hasil bahwa harapan yang diinginkan oleh pihak internal maupun eksternal perusahaan contohnya investor dan kreditor salah satunya adalah pertumbuhan aset perusahaan. Pertumbuhan ini diharapkan dapat memberikan aspek yang positif bagi perusahaan seperti adanya suatu kesempatan berinvestasi di perusahaan tersebut. pertumbuhan perusahaan yang paling mudah dilihat adalah mealui penjualannya. Perusahaan yang tumbuh dan bekrembang tentunya akan memiliki penjualan yang baik. Jadi jika investor ingin menanamkan sahamnya pada perusahaan tersebut maka mereka dapat melihat ke angka penjualan perusahaan tersebut meskipun angka penjualan tidak secara mutlak menentukan bahwa perusahaan tersebut memiliki prospek yang baik. Penelitian mengenai pertumbuhan perusahaan dengan kinerja perusahaan belum banyak dilakukan 
sebelumnya. Dalam penelitian sebelumnya pertumbuhan perusahaan cenderung dikaitkan pada nilai perusahaan serta harga saham.

Kinerja perusahaan juga dapat dipengaruhi oleh mekanisme good corporate governance dimana secara umum dibagi menjadi dua bagian yaitu eksternal dan internal. Dewan komisaris yang dianggap sebagai puncak pengelola internal memiliki peranan terhadap aktivitas pengawasan. Komite audit bertanggung jawab untuk mengawasi laporan keuangan serta pengauditan baik internal maupun eksternal. Kepemilikan manajerial merupakan proporsi saham biasa yang dimiliki oleh para manajemen, yang diukur menggunakan persentase jumlah saham biasa yang beredar. Alasan utama mengapa memilih kepemilikan manajerial pada penelitian ini dikarenakan kepemilikan manajerial merupakan salah satu mekanisme corporate governance utama yang membantu mengendalikan masalah keagenan.

Bagi para investor, dividen merupakan hasil yang diperoleh dari saham yang dimiliki, selain capital gain yang didapat apabila harga jual saham lebih tinggi dibanding harga belinya. Martono dan Harjito (2010:253) menyatakan bahwa "Kebijakan dividen merupakan keputusan apakah laba yang diperoleh perusahaan pada akhir tahun akan dibagi kepada pemegang saham dalam bentuk dividen atau akan ditahan untuk menambah modal guna pembiayaan investasi di masa yang akan datang". Kebijakan ini tentunya adalah bagian yang tidak lepas dari keputusan pendanaan. Kebijakan dividen menurut Gitman (2000) adalah rencana tindakan yang harus diikuti dalam membuat keputusan dividen.

Dermawan (2002), mengatakan bahwa apabila perusahaan bertumbuh dan berkembang maka pada waktunya perusahaan tersebut akan memeroleh 
keuntungan atau laba. Laba perusahaan dibedakan menjadi dua yaitu laba ditahan dan laba yang dibagikan dalam bentuk dividen. Laba ditahan biasanya digunakan perusahaan membiayai berbagai hal yang dapat membantu pertumbuhan perusahaan. emberian dividen secara tidak langsung merupakan isyarat yang diberikan oleh perusahaan mengenai kinerja perusahaan. Jika perusahaan secara konsisten dapat membayarkan dividen dengan nilai yang stabil atau bahkan mengalami peningkatan tiap tahunnya, maka kan berdampak pada respon para investor dimana ini merupakan sinyal postof yang diberikan perusahaan kepada investor. Hal ini pada akhirnya akan dapat meningkatkan harga saham serta nilai perusahaan (Sujoko dan Soebiantoro, 2007).

Contoh kasus yang terkait dengan penelitian ini yaitu pailitnya PT Dwika Aneka Kemasindo Tbk. Perusahaan ini merupakan perusahaan manufaktur yang memproduksi kertas karton dan barang sejenisnya, kasusnya berawal dari kerugian yang dialami perusahaan secara terus-menerus dan ketidakmampuan dari manajemen dalam melunasi kewajibannya yang terus membengkak yang pada akhirnya PT Dwika Aneka Kemasindo Tbk. dinyatakan pailit oleh Pengadilan Niaga Jakarta Pusat. Banyak faktor yang menyebabkan PT Dwika Aneka Kemasindo Tbk pada akhirnya mengalami kepailitan, diantaranya ada indikasi manajeman yang melakukan kelalaian dan tidak mampu dalam menjalankan operasi perusahaan sehingga produksi yang dilakukan terus menurun sepanjang tahun dan berdampak pada kerugian yang dialami perusahaan. Faktor lainnya adalah perusahaan tidak mampu bersaing dengan perusahaan sejenis yang pada akhirnya produk yang dihasilkan perusahaan tidak dapat diterima oleh pasar. Kegagalan manajemen dalam menjalankan perusahaan ini menjadi faktor utama 
perusahaan tidak mampu berjalan dan pada akhirnya kewajiban perusahaan terus membengkak dan akhirnya dinyatakan pailit

Dari kasus tersebut dapat ditarik kesimpulan bahwa kinerja sebuah perusahaan sangatlah berpengaruh terhadap keuntungan ataupun pertumbuhan perusahaan tersebut, oleh sebab itu dalam penelitian ini diguanakan kinerja perusahaan sebagai salah satu variabel, dan faktor-faktor apa saja yang membawa pengaruh terhadap kinerja perusahaan itu sendiri. Berdasarkan latar belakang yang telah diuraikan di atas, peneliti ingin meneliti tentang "Pengaruh Pertumbuhan Perusahaan, Kepemilikan Manajerial dan Kebijakan Dividen Pada Kinerja Perusahaan Manufaktur Yang Terdaftar di BEI”.

Rumusan masalah yang dapat diajukan yaitu: 1) "Apakah pertumbuhan perusahaan berpengaruh pada kinerja perusahaan manufaktur yang terdaftar di bursa efek Indonesia?” 2) “Apakah kepemilikan manajerial berpengaruh pada kinerja perusahaan manufaktur yang terdaftar di bursa efek Indonesia?" 3) “Apakah kebijakan dividen berpengaruh pada kinerja perusahaan manufaktur yang terdaftar di bursa efek Indonesia?”

Tujuan penelitian ini diharapkan agar penelitian memberikan bukti empiris mengenai pengaruh pertumbuhan perusahaan, kepemilikan manajerial dan kebijakan dividen terhadap kinerja perusahaan manufaktur yang terdaftar di bursa efek Indonesia. Selain itu, penelitian ini bagi akademisi diharapkan dapat memberikan kontribusi pada literature akuntansi mengenai pertumbuhan perusahaan, kepemilikan manajerial, kebijakan dividend dan juga kinerja perusahaan. Hasil penelitian ini juga diharapkan dapat membantu investor sebagai bahan pertimbangan dalam pengambilan keputusan investasi. 
Teori yang melandasi penelitian ini adalah teori keagenan. Jansen dan Meckling (1976), menyatakan bahwa "Teori agensi berkembang dalam dua aliran yaitu positivism dan principal agent. Keduanya menggunakan dasar yang sama, yaitu adanya kontrak principal dan agen". Aliran kesatu yakni positivism difokuskan dalam situasi yang bermasalah maksudnya yaitu situasi yang mungkin kedepannya akan dapat menimbulkan konflik kepentingan antara agen, principal dan cara pengelolaankonflik tersebut supaya prilaku agen lebih terkendali pada suatu kepentingan principal, sedangakan menurut aliran principal agen, penerapan di bidang pendelegasian kepada pelaksana pekerjaan yang banyak di jumpai dalam kasus sehari-hari merupakan masalah biaya agensi.

Dasar yang digunakan untuk memahami isu corporate governance yaitu perspektif teori agensi. Kecenderungan timbulnya konflik keagenan diantara principal dan agen karena adanya pemisahan kepemilika oleh principal dengan pengendalian oleh agen dalam sebuah organisasi. Laporan keuangan yang dibuat dengan angka-angka akuntansi diharapkan dapat meminimalkan konflik antara pihak-pihak yang saling berkepentingan (Jensen dan Meckling, 1976). Menurut Berkaoui (2007), principal yang merupakan penanggungjawab kinerja yang didasarkan pada laporan keuangan yang dilaporkan oleh agen, prisnsipal dapat mengukur bagaimana pekerjaan yang dilakukan oleh agen tersebut dalam upaya mencapai tujuan perusahaan. Hal ini nantinya akan digunakan sebagai dasar dalam pemberian kompensasi kepada agen.

Teori bird in the hand merupakan teori ini dikembangkan oleh Myron Gordon (1956) dan John Lintner (1962). Dalam teori ini menyatakan bahwa terdapat korelasi antara nilai perusahaan dengan kebijakan dividen. Dalam teori 
ini menjelaskan bahwa investor memiliki keinginan agar mendapat dividen yang tinggi sesuai dengan tujuan awalnya menanamkan sahamnya di suatu perusahaan.

Menurut Jama'an (2008) Signaling Theory mencakup tindakan perusahaan dalam memberikan sinyal kepada pengguna laporan keuangan. Sinyal ini menggambarkan sejauh mana manajemen sudah berhasil mencapai tujuan perusahaan. Teori sinyal menjelaskan bahwa pemberian sinyal ini bertujuan untuk mengurangi kemungkinan terjadinya asimetri informasi. Menurut Restuti (2006) kualitas informasi yang ada atau di publish dalam laporan keuangan perusahaan akan sebanding memengaruhi keputusan investor. Diperlukan pula berbagai opini dari pihak lain yang netral dalam memberikan pendapat mengenai laporan keuangan perusahaan untuk memastikan bahwa laporan tersebut andal dan dapat digunakan (Jama’an, 2008).

Pertumbuhan perusahaan berkaitan dengan kemampuan perusahaan dalam meningkatkan asetnya. Pertumbuhan ini dapat dipengaruhi oleh berbagai faktor internal maupun eksternal serta pengaruh iklim industry local. Pertumbuhan perusahaan yang cepat mennimbulkan kebutuhan akan dana yang semakin besar pula untuk melakukan ekspansi. Semakin besar kebutuhan untuk pembiayaan mendatang maka semakin besar keiinginan perusahaan untuk menahan laba.

Diyah (2009) menyatakan kepemilikan manajerial merupakan proporsi saham yang dimiliki oleh manajemen yang memiliki suara dalam pengambilan keputusan perusahaan. Suatu kepemilikan saham apabila besar dilihat dari nilai segi ekonominya maka akan memiliki dorongan untuk menyelaraskan kepentingan antara manajer dan principal. Kepemilikann manajerial ini dapat pula merupakan situasi saat manajer sebagai pemegag saham pula yang ditunjyukkan 
I Wayan Diva Pradita Kamajaya dan I.G.A.M. Asri Dwija Putri. Pengaruh...

dari kepemilikan saham perusahaan. Semakin besar manajer memiliki saham perusahaan maka akan semakin produktif manajer tersebut dalam memaksimalkan kinerja perusahaan.

Menurut Aharony dan Swary (1980) dalam Nurhidayati (2006) mengemukakan bahwa informasi yang diberikan pada saat pengumuman dividen lebih berarti daripada pengumuman earning. Kebijakan dividen menurut Martono dan Agus (2010:253) merupakan bagian yang tidak terlepas dari keputusan pendaan perusahaan. Kebijakan dividen (dividend policy) merupakan keputusan apakah laba yang diperoleh perusahaan akan dibagikan dalam bentuk dividen atau ditahan sebagai laba ditahan untuk membiayai investasi perusahaan di masa depan. Kebijakan dividen merupakan suatu kebijakan yang dilakukan dengan pengeluaran biaya yang cukup mahal, karena perusahaan harus menyediakan dana dalam jumlah besar untuk keperluan pembayaran dividen. Banyak perusahaan yang selalu mengkomunikasikan bahwa perusahaannya memiliki prospektif dan menghadapi masalah keuangan sudah tentu akan kesulitan untuk membayar dividen. Perusahaan dengan prospek ke depan yang cerah, akan memiliki harga saham yang semakin tinggi.

Kinerja perusahaan menggambarkan kondisi keuangan suatu perusahaan dimana pengukuran dilakukan dengan menggunakan analisis berbagai rasio keuangan yang berguna untuk mengetahui bagaimana keadaan serta kemampuan keuangan perusahaan yang merupakan cerminan bagaimana prestasi kerja perusahaan dalam periode tertentu. Hal ini berguna agar sumber daya yang ada dapat digunakan secara optimal dalam menghadapi berbagai perubahan yang dapat terjadi (Febrianto, 2013). Kinerja perusahaan juga digunakan untuk 
mengetahui tingkat keefektifan dan seberapa efisien manajemen dalam mencapai tujuan perusahaan.

Setelah berbagai pemaparan di atas maka dapat ditentukan gambaran kerangka konseptual. Dimana kerangka ini menggambarkan hubungan antar variabel bebas dengan variabel terikatnya serta terdapat pula hipotesis penelitian dalam gambar tersebut. Adapun kerangka konseptual dalam penelitian ini disajikan pada gambar 1 sebagai berikut.

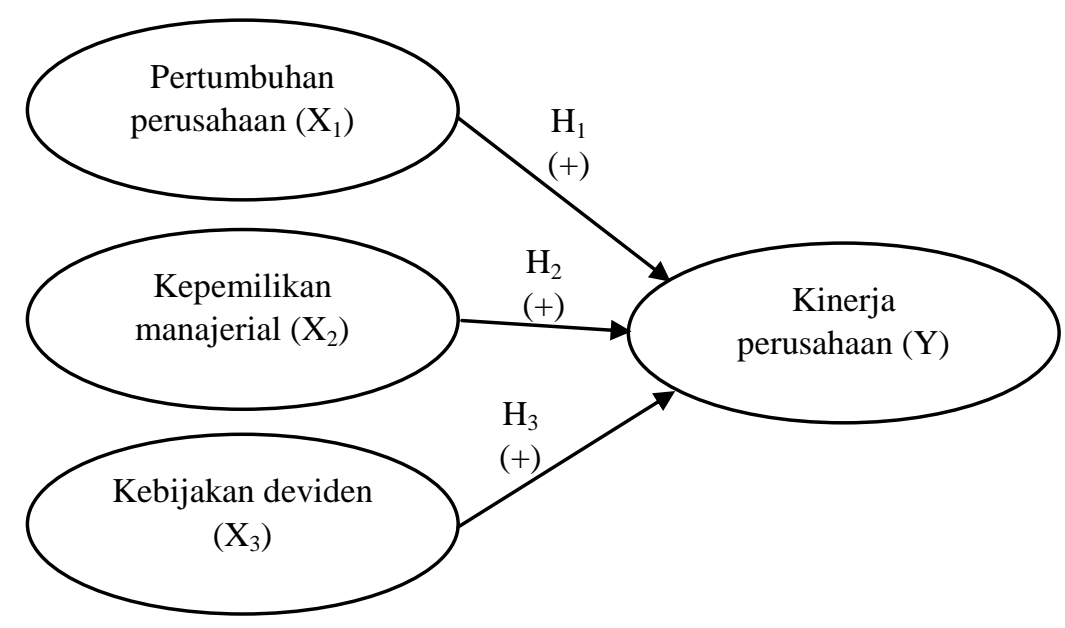

Gambar 1. Kerangka Konseptual

Sumber : Data diolah, 2018

Salah satu faktor yang menentukan struktur modal perusahaan adalah pertumbuhan perusahaan (Pandey, 2001). Hal ini dilihat bahwa perusahaan yang tumbuh dan berkembang membutuhkan dana untuk menjalankan operasi serta melakukan ekspansi. Semakin tinggi pertumbuhan perusahaan maka akan semakin baik citra perusahaan. Hal ini paling mudah terlihat dari adanya peningkatan penjualan perusahaan tiap periode.

Perusahaan yang memiliki pertumbuhan positif akan memperoleh penilaian yang positif di mata investor. Hal ini merupakan sinyal bahwa 
perusahaan memiliki prospek yang baik di masa mendatang. Pertumbuhan perusahaan juga erat kaitannya dengan peningkatan kinerja perusahaan. Hal ini akan berimbas pada peningkatan nilai perusahaan yang diikuti meningkat pula kemakmuran pemegang saham (Brigham dan Houston, 2006).

$\mathrm{H}_{1}$ : Pertumbuhan perusahaan berpengaruh positif pada kinerja perusahaan

Diah dan Erman (2009) menyatakan kepemilikan manajerial merupakan persenan saham yang dimiliki oleh manajemen yang akan berpengaruh terhadap keputusuan manajemen dalam perusahaan. Suatu kepemilikan saham apabila besar dilihat dari nilai segi ekonominya maka akan memiliki dorongan untuk menyelaraskan kepentingan antara manajer dan principal. Menurut Jensen dan Meckling (1976) semakin besar manajer memiliki saham perusahaan maka akan semakin produktif manajer tersebut dalam mencapai kinerja perusahaan yang optimal.

Furest dan King (2000) dalam Suranta (2004) menyatakan bahwa terdapat insider ownership dan nilai pasar akan memiliki hubungan yang positif dalam hubungannya dengan pengendalian kinerja perusahaan. Sehingga dapat dikatakan bahwa terdapat pengaruh yang positif dari corporate insider terhadap kinerja perusahaan, sedangkan penelitian Febrianto (2013) menyatakan bahwa kepemilikkan manajerial berpengaruh terhadap kinerja perusahaan akan tetapi arahnya negatif. Berdasarkan urutan tersebut diatas serta mengacu pada penelitian sebelumnya maka dapat dirumuskan.

$\mathrm{H}_{2}$ : Kepemilikan manajerial berpengaruh positif pada kinerja perusahaan.

Keputusan dividen adalah keputusan perusahaan yang menentukan 
seberapa besar bagian keuntungan yang menjadi hak bagi pemegang saham atau investor (Brigham dan Houstn, 2006). Pembagian dividen menjadi sebuah keputusan, ketika diputuskan dalam rapat umum pemegang saham atau RUPS, yang biasanya terjadi kesepakatan antara manajemen dengan pemegang saham tentang berapa besar yang harus ditahan untuk diinvestasikan kembali ke dalam perusahaan dan beberapa yang dibagikan sebagai dividen.

Peneliti-peneliti empiris tentang kebijakan dividen, pada umunya diarahkan untuk mengetahui mengapa perusahaan membayar dividen? Penelitian yang yang berkaitan dengan agency theory dan kepemilikkan saham oleh pemerintah didokumentasikan oleh Fama dan French (2001); Naser (2004) dan Al-Mulkawi (2008). Mereka menunjukan bahwa perusahaan-perusahaan yang besar serta sebagian besar sahamnya dimiliki oleh pemerintah maka mereka akan cenderung membayar dividen yang tinggi. Hal ini bertujuan untuk mengurangi masalah keagenan (agency problems). Penelitian tentang kebijakan dividen yang berkaitan dengan teori-teori di atas pada umumnya dilakukan pada pasar modal kategori developed markets. Berdasarkan pemaparan tersebut maka dapat dirmuskan hipotesis ketiga dalam penelitian ini yaitu sebagi berikut.

$\mathrm{H}_{3}$ : Kebijakan dividen berpengaruh positif pada kinerja perusahaan.

\section{METODE PENELITIAN}

Penelitian ini menggunakan pendekatan kuantitatif yang dilakukan dengan mendefinisiakan, mengukur data kuantitatif dan statistic objektif melalui perhitungan ilmiah berasal dari data sampel. Tujuan penelitian kuantitatif ini untuk pengembangan dengan model-model matematis serta teori-teori yang 
berkaitan dengan fenomena yang terjadi. Lokasi penelitian ini adalah perusahaan manufaktur yang terdaftar di bursa efek Indonesia (BEI) periode tahun 2013 sampai dengan tahun 2017. Obyek penelitian dalam penelitian ini adalah kinerja perusahaan pada perusahaan manufaktur yang terdaftar di Bursa Efek Indonesia selama tahun 2013 sampai tahun 2017. Variabel terikat dalam penelitian ini adalah kinerja perusahaan yang dilambangkan dengan Y. Variabel bebas dalam penelitian ini adalah pertumbuhan perusahaan, kepemilikan manajerial dan kebijakan dividen yang berturut-turut dilambangkan dengan $\mathrm{X}_{1}, \mathrm{X}_{2}$, dan $\mathrm{X}_{3}$

Menurut Hastuti (2005) dalam Purwani (2010) kinerja perusahaan berupa implementasi dari keputusan yang dibuat manajemen secara berulang yang merupakan hasil dari keputusan individual. Pengukuran kinerja perusahaan dalam penelitian ini menggunakan rasio Tobin's Q. dimana Tobin's Q adalah indikator yang berguna untuk mengukur kinerja perusahaan yang dilihat dari cara manajemen dalam mengelola aset perusahaan (Sudiyanto dan Puspitasari, 2010) dalam pengukuran kinerja perusahaan dengan menggunakan rasio Tobin's Q ini memakai harga saham pada akhir tahun penutupan yaitu pada 31 Desember.

Kallapur dan Trombley (2001) menjelaskan bahwa pertumbuhan perusahaan merupakan kemampuan perusahaan untuk meningkatkan ukuran perusahaan melalui peningkatan aktiva. Perusahaan yang mengadakan ekspansi akan memiliki tingkat pertumbuhan yang cepat. Pertumbuhan perusahaan dihitungan dengan cara mencari selisih dari peningkatan aset dari periode $1 \mathrm{ke}$ periode sebelumnya dan dibagikan dengan jumlah total aset yang dimiliki perusahaan. 
Menurut Atika (2002) kepemilikan manajerialdapat dikatakan sebagai jumlah persenan saham yang dimiliki oleh manajemen yang menentukan suara yang dimiliki dalam pengambilan keputusan perusahaan. Kepemilikan manajerial dihitung dengan jumlah persentase kepemilikan saham manajemen, dibagai dengan jumlah saham beredardan dikalikan $100 \%$.

Kebijakan dividen merupakan keputusan untuk membagikan laba dalam bentuk dividen atau menahannya sebagai laba ditahan untuk membiayai investasi di masa (Martono dan Agus, 2010;253). Kebijakan dividen diproksikan dengan menggunakan dividen payout ratio.

\section{HASIL DAN PEMBAHASAN}

Daerah atau wilayah penelitan yang digunakan dalam penelitian ini adalah Bursa Efek Indonesia (BEI). Perusahaan dipilih dengan menggunakan teknik purposive sampling sesuai dengan kriteria yang telah ditetapkan. Berdasarkan proses seleksi sampel diperoleh 8 perusahaan. Total sampel yang dambil selama 5 tahun adalah sebanyak 40 obyek pengamatan.

Statistik deskriptif berhubungan dengan pengumpulan dan peringkat data yang menggambarkan karakteristik dari masing-masing variabel yang digunakan dalam penelitian ini. Analisis ini berguna untuk menjelaskan karakteristik dari variabel penelitian diantaranya : nilai rata-rata (mean), nilai ekstrim yaitu nilai minimum dan nilai maksimum, standar deviasi. Hasil dari deskriptif tersebut dapat dilihat pada Tabel 1 . berikut. 
Tabel 1.

Hasil Uji Statistik Deskriptif

\begin{tabular}{|c|c|c|c|c|c|}
\hline & $\mathbf{N}$ & Minimum & Maximum & Mean & Std. Deviation \\
\hline $\mathrm{Y}$ & 40 & 0,572132 & 2,208799 & 1,08735638 & 0,390150295 \\
\hline $\mathrm{X} 1$ & 40 & $-0,117518$ & 0,336353 & 0,08424635 & 0,101214762 \\
\hline $\mathrm{X} 2$ & 40 & 0,000046 & 0,608353 & 0,14572589 & 0,208297221 \\
\hline X3 & 40 & 0,000000 & 4,255319 & 0,49376474 & 0,712891799 \\
\hline Valid N (listwise) & 40 & & & & \\
\hline
\end{tabular}

Sumber: Data diolah, 2018

Berdasarkan Tabel 1, variabel Kinerja Perusahaan (Y) memiliki nilai terendahnya (minimum) pada 0,572132 yang dimiliki oleh perusahaan Lionmesh Prima Tbk pada tahun 2015, sedangkan nilai tertingginya (maksimumnya) pada 2,208799 yang dimiliki oleh perusahaan Mandom Indonesia Tbk pada tahun 2014, dengan rata-rata (mean) sebesar 1,08735 dan simpangan baku (standar deviasi) sebesar 0,39015.

Variabel Pertumbuhan Perusahaan $\left(\mathrm{X}_{1}\right)$ memiliki nilai terendahnya (minimum) pada -0,117518 yang dimiliki oleh perusahaan Indofood Sukses Makmur Tbk pada tahun 2016, sedangkan nilai tertingginya (maksimumnya) pada 0,336353 yang dimiliki oleh perusahaan Sekar Laut Tbk pada tahun 2016, dengan rata-rata (mean) sebesar 0,08424635 dan simpangan baku (standar deviasi) sebesar 0,101215 .

Variabel Kepemilikan Manajerial $\left(\mathrm{X}_{2}\right)$ memiliki nilai terendahnya (minimum) pada 0,000046 yang terdapat pada perusahaan Asahimas Flat Glass Tbk pada tahun 2013 hingga 2017, sedangkan nilai tertingginya (maksimumnya) pada 0,608353 yang dimiliki oleh perusahaan Mandom Indonesia Tbk pada tahun 2013 dan 2017, dengan rata-rata (mean) sebesar 0,145725 dan simpangan baku (standar deviasi) sebesar 0,208297. 
Variabel Kebijakan Dividen $\left(\mathrm{X}_{3}\right)$ memiliki nilai rendahnya (minimum) pada 0,000000 yang dimiliki oleh perusahaan Lionmesh Prima Tbk pada tahun 2017, sedangkan nilai tertingginya (maksimum) pada 4,255319 yang dimiliki oleh perusahaan Lion Metal Tbk pada tahun 2014, dengan rata-rata (mean) sebesar 0,49376474 dan simpangan baku (standar deviasi) sebesar 0,712891.

Selanjutnya dilakukan uji asumsi klasik yang meliputi uji normalitas, uji autokorelasi, uji multikolinearitas dan uji heteroskedastisitas. Uji yang pertama adalah uji normalitas. Berdasarkan hasil pengujian SPSS dapat dilihat bahwa nilai Kolmogorov Sminarnov (K-S) sebesar 0,088, sedangkan nilai Asymp. Sig. (2tailed) sebesar 0,200. Hasil tersebut mengindikasikan bahwa model persamaan regresi tersebut berdistribusi normal karena nilai Asymp. Sig. (2-tailed) 0,200 lebih besar dari nilai $\alpha=0,05$.

Uji asumsi klasik yang kedua adalah uji autokorelasi. Berdasarkan hasil uji autokorelasi, nilai DW 1,832 lebih besar dari batas atas (du) yakni 1,6589 dan kurang dari (4-du) 4-1,8589 = 2,3411 sehingga model dikatakan lolos dari uji autokorelasi. Uji selanjutanya yaitu uji multikolinearitas. Berdasarkan pengujian didapatkan hasil bahwa masing-masing variabel bebas mempunyai nilai tolerance yaitu 0,985 (pertumbuhan perusahaan), 0,971 (kepemilikan manajerial), dan 0,982 (kebijakan dividen) lebih besar dari $10 \%(0,10)$ dan nilai VIFF masing-masing variabel bebas tersebut adalah yaitu 1,015 (Pertumbuhan perusahaan), 1,030 (kepemilikan manajerial), dan 1,018 (kebijakan dividen) lebih kecil dari 10 . Berdasarkan nilai tolerance dan VIFF dari masing-masing variabel bebas, hal ini menunjukkan bahwa tidak terjadi gejala multikolinieritas pada model persamaan regresi. 
I Wayan Diva Pradita Kamajaya dan I.G.A.M. Asri Dwija Putri. Pengaruh...

Uji asumsi klasik yang digunakan selanjutnya adalah uji heteroskedastisitas. Nilai signifikansi dari variabel pertumbuhan perusahaan, kepemilikan manajerial, dan kebijakan dividen, masing-masing sebesar 0,946; 0,217 dan 0,065 . Nilai tersebut lebih besar dari 0,05 yang berarti tidak terdapat pengaruh antara variabel bebas terhadap absolute residual. Sehingga tidak terdapat gejala heteroskedastisitas dalam model ini.

Selanjutnya dilakukan uji analisis regresi linear berganda serta uji kelayakn model. Berdasarkan hasil pengolahan data dengan bantuan SPSS, maka didapatkan hasil seperti dibawah ini.

Tabel 2.

Hasil Analisis Regresi Linier Berganda

\begin{tabular}{lccc}
\hline \multicolumn{1}{c}{ Variabel } & $\begin{array}{c}\text { Nilai Koefisien } \\
\text { Regresi }\end{array}$ & t hitung & Nilai Signifikansi \\
\hline Constant & 0,882 & 9,242 & 0,000 \\
Pertumbuhan Perusahaan $\left(\mathrm{X}_{1}\right)$ & 0,872 & 1,558 & 0,128 \\
Kepemilikan Manajerial $\left(\mathrm{X}_{2}\right)$ & 0,893 & 3,264 & 0,002 \\
Kebijakan Dividen $\left(\mathrm{X}_{3}\right)$ & 0,003 & 0,034 & 0,973 \\
R Square & & & 0,253 \\
Adjusted $R$ Square & & & 0,191 \\
F Statistik & & & 4,067 \\
Signifikansi & & & 0,014 \\
\hline Sumber: Data diolah, 2018 & &
\end{tabular}

Berdasarkan hasil diatas, maka diperoleh model regresi sebagai berikut:

$$
Y=0,882+0,872 X_{1}+0,893 X_{2}+0,003 X_{3}+e
$$

Nilai konstanta sebesar 0,882 artinya jika nilai variabel pertumbuhan perusahaan, kepemilikan manajerial, dan kebijakan dividen dianggap konstan maka nilai kinerja perusahaan sebesar 0,882 . Nilai koefisien variabel pertumbuhan perusahaan sebesar 0,872 artinya jika nilai variabel pertumbuhan perusahaan naiknya 1 persen, maka variabel kinerja perusahaan mengalami kenaikan sebesar $87,2 \%$ dengan asumsi variabel bebas lainnya konstan. Nilai koefisien variabel 
kepemilikan manajerial sebesar 0,893 artinya jika nilai variabel kepemilikan manajerial mengalami kenaikan 1 persen, maka variabel kinerja perusahaan mengalami kenaikan sebesar $89,3 \%$ dengan asumsi variabel bebas llainnya konstan. Nilai koefisien variabel kebijakan dividen sebesar 0,003 artinya jika nilai variabel kebijakan dividen mengalami kenaikan 1 persen, maka variabel kinerja perusahaan mengalami kenaikan sebesar $0,3 \%$ dengan asumsi variabel bebas lainnya konstan.

Berdasarkan Tabel 2 diatas maka dapat dilihat juga nilai koefisien determinasi $\left(\mathrm{R}^{2}\right)$, uji kelayakan model (uji F), dan uji hipotesis (uji t) sebagai berikut. Koefisien determinasi $\left(\mathrm{R}^{2}\right)$ fungsinya dilakukan pengukuran adalah untuk mengetahui seberapa besar persenan pengaruh dari variabel bebas pada variabel dependennya. Nilai determinasi total sebesar 0,253 mempunyai arti bahwa sebesar 25,3\% variasi kinerja perusahaan dipengaruhi oleh variasi pertumbuhan perusahaan, kepemilikan manajerial, dan kebijakan dividen sedangkan sisanya sebesar 74,7\% dijelaskan oleh faktor lain yang tidak dimasukkan ke dalam model. Uji kelayakan model (Uji F) digunakan untuk mengetahui apakah model analisis regresi linier berganda dalam penelitian ini layak digunakan. Pada Tabel 2 diperoleh nilai antar kelompok pembanding $=3$, nilai dalam kelompok penyebut $=$ 36 pada $\alpha=0,05$ maka nilai $F$ tabelnya adalah F $0,05(3,36)=2,87$ Sedangkan $F$ hitung $=4,067$. Nilai $\mathrm{F}$ hitung $>\mathrm{F}$ tabel, 4,067 > 2,87, dengan nilai signifikansi $0,014<0,05$. Maka $\mathrm{H}_{0}$ ditolak pada taraf nyata $0,05 \quad\left(\mathrm{H}_{1}\right.$ diterima $)$. Kesimpulannya, pada kelompok yang diuji memiliki perbedaan yang nyata (signifikan) berarti bahwa pertumbuhan perusahaan, kepemilikan manajerial, dan 
kebijakan dividen secara simultan berpengaruh signifikan terhadap kinerja perusahaan.

Kemudian dilakukan uji hipotesis t dimana uji hipotesis (Uji t) digunakan untuk menguji signifikansi masing-masing variabel secara parsial. Berdasarkan Tabel 4 hasil uji $\mathrm{t}$ memiliki arti sebagai berikut. Berdasarkan hasil analisis pengaruh pertumbuhan perusahaan pada kinerja perusahaan diperoleh nilai signifikansi sebesar 0,128 dengan nilai koefisien regresi sebesar 0,872. Nilai signifikansi $0,128>0,05$ mengindikasikan bahwa $\mathrm{H}_{0}$ diterima dan $\mathrm{H}_{1}$ ditolak. Hasil ini mempunyai arti pertumbuhan perusahaan tidak berpengaruh pada kinerja perusahaan.

Hal ini mengindikasikan bahwa pertumbuhan perusahaan mengalami peningkatan maka itu tidak diikuti oleh meningkatnya kinerja perusahaan tersebut. Pertumbuhan perusahaan yang diukur melalui perubahan aset tidak dapat menjamin bahwa kinerja perusahaan tersebut baik. Adanya pertumbuhan perusahaan bisa saja disebabkan akibat adanya investasi dalam bentuk aset yang pembiayaannya melalui utang. Peneleitian ini juga sejalan dengan penelitian yang telah dilakukan oleh Armini (2015). Selain itu pertumbuhan perusahaan memiliki nilai rata-rata yang rendah yakni hanya 0,08 sehingga tidak dapat dipastikan apakah perusahaan memiliki kinerja baik dan sinyalnya juga belum mampu ditangkap investor.

Berdasarkan hasil analisis pengaruh kepemilikan manajerial pada kinerja perusahaan didapatkan nilai sig yakni 0,002 dengan nilai koefisien regresi sebesar 0,893. Nilai signifikansi $0,002<0,05$ menunjukkan $\mathrm{H}_{0}$ ditolak dan $\mathrm{H}_{2}$ diterima. Hasil ini berarti kepemilikan manajerial berpegaruh pada kinerja perusahaan. 
Jensen and Meckling (1976) menyatakan bahwa kepemilikan saham manajerial dalam perusahaan mendorong untuk menciptakan kinerja perusahaan secara optimal dan memotivasi manajer untuk berhati-hati karena ikut menanggung konsekuensi atas tindakannya. Semakin besar persenan kepemilikan oleh manajerial pada perusahaan, maka manajemen akan semakin terdorong untuk mengoptimalkan nilai perusahaanb. Jika kepentingan manajer dan pemilik sejajar maka dapat mengurangi konflik keagenan.

Hasil penelitian ini mendukung penelitian Santana (2016), Gea (2014), Agustia (2013) yang menyatakan hubungan agensi memiliki kecendrungan potensi munculnya konflik yang lebih besar, yaitu ketika manajemen perusahaan memiliki kurang dari $100 \%$ saham milik perusahaan. Konflik ini didasari dari keinginan agen untuk mendapat kompensasi yang lebih tinggi atas kinerjanya atau mendapatkan fasilitas demi kenyamanan pribadinya.

Berdasarkan analisis yang dilakukan pada kebijakan dividen terhadap kinerja perusahaan diperoleh nilai signifikansi sebesar 0,973 dengan nilai koefisien regresi sebesar 0,003. Nilai signifikansi $0,973>0,05$ mengindikasikan bahwa $\mathrm{H}_{0}$ diterima dan $\mathrm{H}_{3}$ ditolak. Hasil ini berati menunjukkan kebijakan dividen tidak berpengaruh pada kinerja perusahaan.

Kebijakan dividen merupakan pemilihan keputusan untuk membagikan laba dalam bentuk dividen ataukah menahannya sebagai laba ditahan yang bertujuan untuk diinvestasikan kembali dalam perusahaan. Berdasarkan theory bird in the hand besarnya dividen yang dibagikan akan menjadi daya Tarik bagi investor karena mereka lebih menyukai dividen karena sifatnya yang lebih pasti. 
Dengan pemberian dividen yang tinggi menyebabkan banyaknya investor yang tertarik untuk berinvestasi dalam perusahaan tersebut.

Namun teori tersebut tidak sepenuhnya terbukti dari hasil pengujian yang menunjukan bahwa kebijakan dividen tidak berpengaruh terhadap kinerja dari perusahaan. Hal tersebut terbukti sesuai dengan teori yang dikemukakan oleh Miller dan Modligani yang menyatakan bahwa kinerja perusahaan tidak dipengaruhi oleh kebijakan dividen. Meningkatnya nilai dividen tidak selalu diikuti dengan meningkatnya kinerja perusahaan. Karena kinerja perusahaan ditentukan oleh seberapa efektifnya kemampuan perusahaan dalamenghasilkan laba dari aset-aset perusahaan atau kebijakan investasinya. Sejalan juga dengan penelitian yang dilakukan oleh Asri (2015) faktor yang berpengaruh besar terhadap kinerja sebuah perusahaan adalah bagaimana kualitas sumber daya manusia yang dimiliki oleh perusahaan tersebut dan juga penerapan Good Corporate Governance di dalam perusahaan. Kusumastuti (2013) juga memberikan pendapatnya dengan memeroleh capital gain lah pemegang saham ingin mengambil keuntungan jika dilihat bahwa investor tesebut ingin mengambil untung dalam jangka waktu pendek.

Implikasi penelitian ini dibagi atas dua jenis; 1) implikasi teoritis yang menghasilkan simpulan terdapat bukti empiris yang diperoleh dan hasil yang sesuai dengan teori yang dipakai melalui penelitian ini terkait hasil penelitian data yang dilakukan. Hasil uji penelitian ini ditemukan satu dari tiga variabel independen berpengaruh signifikan pada kinerja perusahaan. Kepemilikan manajerial merupakah variabel independen yang memberikan pengaruh signifikan 
pada kinerja perusahaan. 2) implikasi praktisnya semoga hasil penelitian ini mampu membantu perusahaan dalam pertimbangan pengambilan keputusan. Serta pihak investor pun harusnya dapat melihat berbagai faktor sebelum berinvestasi selain faktor dalam penelitian ini yang mungkin dapat memengaruhi terjadinya atau turun naiknya kinerja perusahaan.

\section{SIMPULAN}

Kesimpulan dari penelitian ini yaitu: 1) Pertumbuhan perusahaan tidak berpengaruh pada kinerja perusahaan, hal ini mungkin disebabkan oleh perusahaan dalam melakukan investasi asetnya lebih banyak menggunakan dana yang berasal dari pijaman bukan dari laba yang dihasilkan oleh operasi perusahaan. sehingga meningkatnya pertumbuhan perusahaan tidak mempengaruhi kinerja dari perusahaan tersebut. 2) Kepemilikan manajerial berpengaruh pada kinerja perusahaan, hasil pengujian ini membuktikan teori Jensen and Meckling (1976) menyatakan bahwa dengan adanya kepemilikan saham oleh manajemen maka akan memotivasi manajer dalam menciptakan kinerja perusahaan yang optimal, sehingga kepemilikan manajeeial berpengaruh besar terhadap kinerja perusahaan. 3) Kebijakan dividen tidak berpengaruh pada kinerja perusahaan, hal ini sesuai dengan teori yang dikemukakan Miller dan Modligani yang menyatakan bahwa kebijakan dividen tidak mempengaruhi kinerja perusahaan, karena kinerja perusahaan ditentukan oleh seberapa efektifnya kemampuan perusahaan dalam menghasilkan laba dari aset-aset perusahaan atau kebijakan investasinya. 
Adapun beberapa hal yang dapat disarankan sesuai dengan hasil pembahasan hingga kesimpulan yang disajikan pada penelitian ini meliputi: 1) Ada beberapa faktor yang mempengaruhi kinerja perusahaan manufaktur yang ada di Indonesia, salah satunya yang dibuktikan dalam penelitian ini adalah kepemilikan manajerial, maka dari itu para calon investor dapat mengetahui dari segi mana perusahaan tersebut bisa dilihat telah menjalankan operasi perusahaan nya dengan baik. Sehingga investor tidak salah dalam menanamkan dananya untuk investasi di perusahaan khusunya perusahaan manufaktur. 2) Para investor dan calon investor diharapkan mampu menyimak laporan keuangan yang dipublikasikan perusahaan setiap tahunnya agar mengetahui bagaimana pengelolaan perusahaan tersebut dilakukan dan mengerti terkait perkembangan nilai perusahaan tersebut di masa mendatang. 3) Peneliti selanjutnyadapat memperluas objek penelitian baik dari segi bidang usaha, periode penelitian, maupun variabel penelitian. Karena kinerja perusahaan itu sangat penting sebab kita bisa tau bagaimana perusahaan tersebut dijalankan, dan faktor yang mempengaruhinya. Maka dari itu masih banyak variabel yang bisa digunankan peneliti selanjutnya dalam meneliti kinerja sebuah perusahaan.

\section{REFERENSI}

Agus Sartono. (2001). Manajemen Keuangan Teori dan Aplikasi. Yogyakarta: BPEF-Yogyakarta.

Aharony Joseph dan Itzhak Swary. (1980). "Quarter Dividend and Earnings Annaoncement and Stocholders Return : An Empirical Analysis" The Journal Of Finance, No 1.

Atika Jauhari Hatta. (2002). Faktor-Faktor yang Mempengaruhi Kebijakan Dividen: Investigasi Pengaruh Teori Stakeholder JAAI Volume 6 No. 
2, Desember 2002.

Asri I G. A. M . Dwija Putri dan G. K. Agung Ulupui. (2017). Pengantar Corporate

Asri I G. A. M. Dwija Putri. (2015). Sumber Daya Manusia, Good Corporate Governance, dan Kinerja Perusahaan. E-Jurnal Akuntansi Universitas Udayana.

Beiner, S., W. Drobetz, F. Schmid dan H. Zimmermann. (2003). "Is Board Size An Independent Corporate Governance Mechanism?".

Berle, A. A., \& Means, G. (1932). "The Modern Corporation and Private Property”. New York: Macmillan.

Brigham E.F. dan Houston J.F. (2001). Manajemen Keuangan. Edisi Delapan. Jakarta:Erlangga.

Demsetz H. (1983). "The Structure of Equity Ownership and the Theory of the Firm”. The Journal of Law and Economics, 26, pp:375-390.

Dermawan, Sjahrial. (2002). Manajemen Keuangan, Edisi 3. Medan: Mitra Wacana.

Diyah Pujiati, Widanar, Erman. (2009). "Pengaruh Struktur kepemilikan terhadap Nilai Perusahaan: Keputusan Keuangan Sebagai variabel Intervening". Jurnal Ekonomi Bisnis dan Ventura, Vol. 12. No.1, hal 7186.

Febrianto Danang. (2013). Analisis penerapan good corporate governance terhadap kinerja Perusahaan (studi empiris pada perusahaan yang terdaftar di BEI tahun 2008-2012). Jurnal Universitas Islam Negeri Syarif Hidayatullah.

Ghozali. (2017). Aplikasi Analisis Multivariat dengan Program IBM SPSS 23. Semarang:Badan Penerbit Universitas Diponegoro.

Gitman J. Lawrence. (2000). Principles of Managerial Finance, 10th Edition. San Diego State University. USA.

Gordon Myron and John Lintner. (1956). "Distribution of Income of Corporations Among Dividend, Retained Earning and Taxes". The American Economic Review, May.

Husein Umar. (2011). Metode Penelitian Untuk Skripsi dan Tesis Bisnis Edisi 11. Jakarta: PT Raja Grafindo Persada

Jama'an. (2008). Pengaruh Mekanisme Corporate Governance dan Kualitas 
Kantor Akuntan Publik Terhadap Integritas Informasi Laporan Keuangan (Studi Pada Perusahaan Publik Di BEJ). Jurnal Akuntansi.Universitas Diponegoro, Semarang.

Jensen M., dan W. Meckling. (1976). "Theory of The Firm: Managerial Behavior, Agency Cost, and Ownership Structure". Journal of Financial Economics, 3(4), pp: 305-360.

Jogiyanto H.M. (2002). Analisis Dan Perancangan Sistem Informasi. Yogyakarta: Andi Offset.

Lang, L. and Stulz, R. (1994). “Tobin's q, Corporate Diversification, and Firm Performance". Journal of Political Economy, 102(6), pp: 1248-1280.

Lee S. and Ryu.K. (2003). "Management Ownership and Firm's Value: An Empirical Analysis using Panel Data". Department of Economics Seoul National University.

Lindenberg, E.B, and Ross, S.A. (1981). "Tobin's q Ratio and Industrial Organization". Journal of Business, 54 (1), pp:1-32.

Martono SU dan D. Agus Harjito. (2010). Manajemen Keuangan, Edisi Ketiga, Yogyakarta : Ekonisia.

Mc.Connell, J.J., dan Servaes, H. (1990). "Additional Evidence of Equity Ownership and Corporate Value". Journal of Financial Economics, 27(1), pp:595-612.

Murhadi Werner. R. (2008). "Studi Kebijakan Deviden: Anteseden dan Dampaknya Terhadap Harga Saham", Jurnal Fakultas Ekonomi, Jurusan Manajemen, Universitas Surabaya

Murhadi Werner. R. (2008). "Studi Kebijakan Deviden: Anteseden dan Dampaknya Terhadap Harga Saham", Jurnal Fakultas Ekonomi, Jurusan Manajemen, Universitas Surabaya.

Pattanayak M. (2005). "Insider Ownership and Firm Value: Evidence from Indian Corporate Sector”. Jawaharlal Nehru University, New Delhi.

Putu Riska Amanda Dewi Dan I.G.A.M Asri Dwija Putri. (2017). Pengaruh Kebijakan Dividen Pada Nilai Perusahaan Dengan Pengungkapan CSRDan GoodCorporateGovernance Sebagai Pemoderasi. E-Jurnal Akuntansi Universitas Udayana.

Restuti Maria Immaculata. (2006). Pengaruh Pertumbuhan Perusahaan Terhadap Peringkat Obligasi Dan Yield Obligasi. Jurnal Akuntansi dan Keuangan, Volume 1 No 3, 2007. 
Sefiana Eka. (2009). Pengaruh Good Corporate Governance terhadapManajemen Laba pada PerusahaanPerbankan yang telahGo Publik di BEI. Jurnal Ekonomi, Fakultas Ekonomi Universitas Gunadharma, Jakarta.

Shleifer A dan R.W. Vishny. (1997). "A Survey of Corporate Governance". Journal of Finance, 52(2): pp:737-783.

Sudiyanto B. dan Puspitasari, E. (2010). Tobin's Q dan Altman Z-Score sebagai Indikator Pengukuran Kinerja Perusahaan. Kajian Akuntansi, Pebruari 2010, 2(1): h:9-21.

Sugiyono. (2017). Metode Penelitian Kuantitatif, Kualitatif dan $R \& D$. Bandung: PT Alfabet.

Sujoko dan Subiantoro. (2007). Pengaruh Kepemilikan Saham, Leverage, Faktor Intern dan Faktor Ektern Terhadap Nilai Perusahaan (Studi Empiris Pada Perusahaan Manufaktur di Bursa Efek Jakarta). Jurnal Manajemen dan Kewirausahaan, 9(1), h:41-48.

Syahnaz Melisa. (2012). Pengaruh Corporate Social Responsibility Terhadap Kinerja Keuangan Perusahaan Perbankan. Jurnal Ilmiah Mahasiswa FEB Uiversitas Brawijaya.

Wolk et al. (2001). Accounting Theory: A Conceptual an Institutional Approach. Fifth Edition. South-Western College Publishing. 